\title{
Influence of Cement Content on Recycled Aggregates Concrete Properties
}

\author{
Athanas KONIN (Corresponding author) \\ Institut National Polytechnique Félix HOUPHOUET-BOIGNY \\ BP 1093 Yamoussoukro, Côte d'Ivoire \\ Tel: 225-30-64-36-32Ｅ-mail: kathanas@yahoo.fr \\ David Mangoua KOUADIO \\ Laboratoire du Bâtiment et des Travaux Publics \\ 04 BP 03 Abidjan 04, Côte d'Ivoire \\ Tel: 225-21-21-23-35_E-mail: madok83@yahoo.fr
}

\begin{abstract}
This article presents the results of an experimental investigation carried out to study the influence of cement content on the properties of recycled aggregates concrete. Five concrete mixtures (containing natural aggregates or recycled ones) with different cement content $\left(250,300,350,400\right.$ and $\left.450 \mathrm{~kg} / \mathrm{m}^{3}\right)$ were studied. Tests were performed to measure porosity to water, permeability to gas and compressive strength (at 2, 7 and 28 days). The results indicated that an increase in cement content (over $300 \mathrm{~kg} / \mathrm{m}^{3}$ ) allows to reduce significantly the porosity to water and to enhance the compressive strength of recycled aggregates concrete. Correlations based on properties of these concrete are presented. That allows to apply the formulation method of natural aggregates concrete to prepare recycled aggregates concrete.
\end{abstract}

Keywords: Natural aggregates, Recycled aggregates, Porosity to water, Compressive strength, Cement content

\section{Introduction}

Nowadays, the treatment of waste becomes a priority. We can store them after processing or, better, recycle them in a new product. The re-use of demolition waste has increased as recycling technologies have been developed and improved during the last years (RILEM TC, 2000; RILEM TC, 2004; SBEICO, 2009). Unfortunately, the amount of concrete demolition waste is still increasing world wide. Taking into account that concrete will continue to be the dominant construction material in the future, several research projects have been conducted on the use of recycled aggregates in concrete. The potential benefits and drawbacks of using recycled aggregate concrete have been studied (Topcu, 1995; Neville, 2000; Tu et al., 2006; Zega et al., 2010).

The use of recycled aggregate generally increases the drying shrinkage, creep and porosity to water and decreases the compressive strength of concrete compared to those of natural aggregate concrete (Sri and Tam, 1985; Hansen, 1996; Wirquin et al., 2000; Poon et al., 2002; Domingo et al., 2010). However, the shortcomings of using recycled aggregate can be mitigated by increasing the cement content into the concrete mixture since it is well-known that the amount of cement has an effect on concrete's compressive strength and porosity to water (Tavakoli and Sorousian, 1996; Limbachiya et al., 2007).

In Côte d'Ivoire, the use of recycled aggregates in the manufacture of concrete is still at artisanal stage, no standard and specifications concerning the use of these materials exist. Moreover, the natural aggregate resources are limited, recycled aggregates can be used as a supplement to natural aggregates or under certain conditions, instead of them. That can constitute an alternative to environmental preservation and satisfying the needs of sustainable development.

The aim of this paper is to study the effect of cement content on recycled aggregates concrete properties. In the study, the influence of cement content on compressive strength, permeability to gas and porosity to water on recycled aggregate concrete were investigated.

The final objective of this work is to establish correlation between recycled aggregate concrete and natural aggregate concrete. 


\section{Experimental program}

\subsection{Materials}

A Portland cement type CPA CEM II 32.5 is used in the concrete mixtures. The properties of cement are given in Table 1.

Natural and recycled aggregates were used as the coarse aggregate in the concrete mixtures. For this study, crushed granite was used as the natural aggregate and recycled aggregate sourced from demolition waste was used. The porosity to water of the aggregate was determined. Natural siliceous sand was used as the fine aggregate in the concrete mixture. The physical and mechanical characteristics of the coarse aggregate are shown in Table 2.

\subsection{Concrete mixtures}

The concrete mixtures were formulated with five different cement contents $\left(250,300,350,400\right.$ and $\left.450 \mathrm{~kg} / \mathrm{m}^{3}\right)$. Full replacement of natural coarse aggregate by recycled aggregate was adopted, keeping constant the coarse aggregate volume. Water proportioning was adjusted to obtain concrete having a value with the slump test of 8 $\mathrm{cm}$. The absolute volume method was adopted to design the mix proportion of the concrete compositions as shown in Table 3. The notations used in table 3 are as follows:

- NAC : Concrete made with natural coarse aggregate,

- RAC : Concrete made with recycled coarse aggregate.

\subsection{Specimens casting and curing}

For each composition, cylindrical specimens of $\phi 16 \times 32 \mathrm{~cm}$ were cast. Specimens were used to determine the physical and mechanical properties of concrete. All samples were cast in steel moulds and compacted using a vibrating needle. After their withdrawing from the moulds, the specimens for porosity to water and permeability to gas were kept in a saturated chamber for 7 days, then sawed in 4 cylindrical specimens of $5 \mathrm{~cm}$ in thickness (Figure 1) which were dried at $50^{\circ} \mathrm{C}$ in an air forced oven during 3 days, after that, each sample was sealed with thin plastic sheet and put in a chamber at the same temperature for humidity redistribution until 28 days of age when they were tested. The others specimens were cured in a water tank at $27 \pm 1^{\circ} \mathrm{C}$ until test ages were reached.

\subsection{Physical and mechanical tests}

Tests for the determination of physical and mechanical properties have been carried out on the samples.

- For the physical properties, the tests carried out are:

- Porosity to water test: porosity was measured by total satured water method according to AFPC-AFREM (1997) procedure. The initial weight of the specimens were determined $\left(M_{a}\right)$ and then immersed in tanks containing water. The specimens were kept immersed until they reached a constant weight $\left(\mathrm{M}_{\mathrm{w}}\right)$. After that, they were moved to an oven and maintained at $105^{\circ} \mathrm{C}$ until they reached a constant weight $\left(\mathrm{M}_{\mathrm{d}}\right)$.

- Permeability to gas test: the apparatus known as CEMBUREAU gas permeametre was used for the determination of permeability which is a constant head permeametre and is becoming a standard tool for permeability measurement. Nitrogen gas was used as the permeating fluid. That supplies the apparent permeability of the material dependent on the pressure of injection. To determine the intrinsic permeability, the relation proposed by Klinkenberg (1941) was used.

- For the mechanical properties, it relates to the testing of:

- Compressive strength: it was determined using a PERRIER compression machine with a loading capacity of $300 \mathrm{kN}$. The compressive strength tests were carried out at the ages of 2, 7 and 28 days.

\section{Results and Discussion}

\subsection{Porosity to water}

The results of porosity to water given on figure 2 are the average of 4 measurements on 4 specimens of the same sample. This figure shows that the porosity to water decreases with the increase of cement content for all concrete. As expected, the values of porosity of normal aggregate concrete are low than those of recycled aggregate concrete. However, for the concrete with high cement content $\left(350\right.$ to $\left.450 \mathrm{~kg} / \mathrm{m}^{3}\right)$, the difference between mixtures with recycled and natural aggregates is less than the others. This is due to the better matrix quality. With low cement content compositions, there is a more porous matrix involving the participation of the 
recycled aggregates.

Indeed, in the case of natural aggregates concrete, the porosity is mainly due to the network of the capillary pores (concrete is by nature a porous material). While in the case of recycled aggregates concrete, besides this network of capillary pores, there are mechanical cracks existing in the recycled aggregates. That increases strikingly the porosity of these concretes. Figure 3 schematizes the progress of the water in these two types of concrete.

\subsection{Permeability to gas}

Figure 4 gives the results of the measures of permeability to gas. The results are presented as permeability coefficient obtained from the measured flux of nitrogen at different pressures through the specimen. This figure shows that the permeability coefficient decreases with the increase in cement content. The results are in the same way of those of porosity to water. For the high cement content, the difference between nitrogen permeability of recycled aggregates concrete and natural aggregate concrete is less than for low cement content. Comparing the results of mixtures with recycled aggregates to those with natural aggregate of lower cement content, it can be said that to achieve the same level of nitrogen permeability for the two concrete, it is necessary to increase the cement content. Similar results have been obtained by Kou et al. (2008) on recycled aggregate concrete containing fly ash.

Not withstanding the fact that natural aggregates concrete are better physical properties than those of recycled one (Domingo et al., 2010), the porosity to water and gas permeability of recycled aggregate concrete tend to decrease with an increase in the cement content.

\subsection{Compressive strength}

Each value presented in Table 4 is the average of three measurements. For all tested samples, the compressive strength of concrete made with recycled aggregates is lower than that of concrete made with natural aggregates. These results confirm the role played by the Interfacial Transition Zone (ITZ) in the resistance of concrete (Maso, 1980). Indeed, the works of Konin et al (1998) showed that even in the case of high-performance concrete, the paste-aggregate transition zone is a zone of low resistance, because of his big porosity. And as more porous is the concrete and less resistant it is, the values obtained were predictable. However, the average decrease is low for concrete with low cement content, the variations are below $5 \%$ for mixtures with 250 to $300 \mathrm{~kg} / \mathrm{m}^{3}$ cement content, whereas the variations are over $8 \%$ for mixtures with high cement content (over $300 \mathrm{~kg} / \mathrm{m}^{3}$ ). Nevertheless, the higher strength decrease was $10 \%$ at 28 days for mixture with $450 \mathrm{~kg} / \mathrm{m}^{3}$ of cement.

\subsection{Relation between recycled aggregate concrete and natural aggregate concrete}

Figures 5 to 7 present the relations between properties of recycled aggregates concrete and those of natural aggregates concrete. On each figure, an equation and a correlation coefficient are presented.

Figure 5 presents the relation between the porosity to water of recycled aggregates concrete and that of natural aggregates concrete. The porosity to water of recycled aggregates concrete is strictly linked to that of natural aggregates concrete. The coefficient of correlation is 0.98 .

Figure 6 presents the relation between the nitrogen permeability of recycled aggregates concrete and that of natural aggregates concrete. The nitrogen permeability of recycled aggregates concrete is strictly linked to that of natural aggregates concrete. The coefficient of correlation is 0.94 .

Figure 7 presents the relation between the compressive strength of recycled aggregates concrete and that of natural aggregates concrete. The compressive strength of recycled aggregate concrete is strictly linked to that of natural aggregate concrete. The coefficient of correlation is $0.99,0.98$ and 0.99 respectively at 2,7 and 28 days.

From these data, it is possible to obtain a reduction factor " $r$ " which allows to estimate the compressive strength of recycled aggregates concrete when that of natural aggregates concrete is known for the same proportion of concrete. This coefficient can also be used to adapt the formulation method of natural aggregates concrete to recycled aggregates concrete. So, to produce a recycled aggregates concrete with compressive strength $f_{\text {cr }}$, it is enough to use proportion of mixture corresponding to a natural aggregates concrete with compressive strength: $\mathrm{f}_{\mathrm{cm}}=\mathrm{f}_{\mathrm{cr}} / \mathrm{r}$.

For this study, the main value of the coefficient " $r$ " is worth 0.92 as indicated in Table 5 below.

\section{Conclusion}

The presented study concerns the possibility of use recycled aggregates in the formulation of concrete as a replacement of natural aggregates. At the end of this experimental study, the following conclusions can be drawn: 
- The use of recycled aggregates produces concrete with lower performances related to durability properties, mainly due to the high porosity of these aggregates. Nevertheless, the use of high cement content (over $300 \mathrm{~kg} / \mathrm{m}^{3}$ ) allows improving recycled aggregate concrete properties.

- The variation between the compressive strength of recycled aggregates concrete and those of natural aggregates concrete are lower than $10 \%$ independently to cement content.

- The correlations are presented between the properties recycled aggregates concrete and those of natural aggregates concrete.

- A reduction factor " $\mathrm{r}$ " is determined that allows to adapt the formulation of natural aggregates concrete to recycled aggregates concrete.

The results confirm the opportunity of a large use of recycled aggregates in the manufacturing of concretes. The use of these aggregates constitutes an undeniable ecological contribution.

\section{References}

AFPC-AFREM. (1997). Durabilité des bétons, méthodes recommandées pour la mesure des grandeurs associées à la durabilité, compte-rendu des journées techniques de l'AFPC-AFREM, France, 11-12 Décembre.

DOMINGO, A., LAZARO, C., GAVARRE, F. L., SERRANO, M. A. \& LOPEZ-COLINA, C. (2010). Long term deformation by creep and shrinkage in recycled aggregate concrete, Materials and Structures, Vol. 43. PP 1147-1160.

HANSEN, J. C. (1996). Recycling of demolished concrete and masonry. In RILEM report 6, Ed. E \& FN Spon.

KLINKENBERG, L. J (1941). The permeability of porous media to liquids and gases, American Petroleum Institute, Drilling and Production Practice.

KONIN, A., FRANCOIS, R. \& ARLIGUIE, G. (1998). Penetration of chloride in relation to the microcracking state into reinforced ordinary and high strength concrete, Materials and Structures, vol. 31. PP 310-316.

KOU, S. C., POON, C. S., \& CHAN, D. (2008). Influence of fly ash as a cement addition on the hardened properties of recycled aggregate concrete, Materials and Structures, Vol. 41. PP 1191-1201.

MASO, J. C. (1980). La liaison entre les granulats et la pâte de ciment hydraté. In $7^{\text {̀̀me }}$ Congrès International de Chimie des ciments, Rapport principal.

LIMBACHIYA, M. C., MARROCHINO, E., \& KOULOURIS, A. (2007). Chemical-mineralogical characterization of coarse recycled concrete aggregate, Waste Management, vol. 27. PP 201-208.

NEVILLE, A. M. (2000). Propriétés des bétons, Ed. Eyrolles.

POON C. S., KOU, S. C., \& LAM, L. (2002). Use of recycled aggregates in molded concrete bricks and blocks, Construction and Building Materials, vol. 16. PP 281-289.

RAO, A., JHA K. N., \& MISRA, S. (2007). Use of aggregates from recycled construction and demolition waste in concrete, Resource Conservation and Recycling, Vol. 50. PP 71-81.

RILEM T.C. (2000). Workshop on Use of recycled materials as aggregates in the construction industry, France, 11-12 Septembre. Technical communications.

RILEM T. C. (2004). Conference on use of the recycled materials in building and structures, Espagne, 9-11 Novembre. Technical communications.

SBEICO (2009). $I^{\text {st }}$ International conference on Sustainable Built, Environment, Infrastructures in developing Countries, Algérie, 12-14 Octobre. Technical communications.

SRI RAVINDRARAJAH, R. \& TAM, C. T. (1987). Recycling concrete as fine aggregate in concrete, International Journal of Cement Composites and Lightweight Concrete, vol. 9. PP 235-241.

TAVAKOLI, M. \& SOROUSHIAN, P. (1996). Strength of recycled aggregate concrete made using field demolished concrete as aggregate, ACI Materials Journal, Vol. 93. PP 178-181.

TOPCU, I. B. \& GUNCAN, N. F. (1995). Using waste concrete as aggregate, Cement and Concrete Research, vol. 25. PP 1385-1390.

TU, T. Y., CHEN, Y. Y. \& HWANG, C. L. (2006). Properties of HPC with recycled aggregates, Cement and Concrete Research, vol. 36. PP 943-950. 
WIRQUIN, E., ZAHARIEVA, R. H., \& BUYLE-BODIN, F. (2000). Utilisation de l'absorption d'eau des bétons comme critère de leur durabilité - Application au bétons de granulats recyclés, Materials and Structures, vol. 33. PP 403-408.

ZEGA, C.J., VILLAGRAN-ZACCARDI, Y. A., \& DI MAIO, A. A. (2010). Effect of natural coarse aggregate type on the physical and mechanical properties of recycled coarse aggregate, Materials and Structures, vol. 43.PP 195-202.

Table 1. Chemical, physical and mechanical properties of cement

\begin{tabular}{|l|l|c|}
\hline \multirow{5}{*}{ Chemical compositions (\%) } & $\mathrm{Al}_{2} \mathrm{O}_{3}$ & 6.94 \\
\cline { 2 - 3 } & $\mathrm{CaO}$ & 54.50 \\
\cline { 2 - 3 } & $\mathrm{Fe}_{2} \mathrm{O}_{3}$ & 3.30 \\
\cline { 2 - 3 } & $\mathrm{MgO}$ & 1.68 \\
\cline { 2 - 3 } & $\mathrm{SO}_{3}$ & 2.05 \\
\cline { 2 - 3 } & $\mathrm{SiO}_{2}$ & 17.49 \\
\hline \multirow{3}{*}{ Physical properties } & Density $\left(\mathrm{g} / \mathrm{cm}^{3}\right)$ & 2.98 \\
\hline \multirow{3}{*}{ Compressive strength $(\mathrm{MPa})$} & Specific surface $\left(\mathrm{cm}^{2} / \mathrm{g}\right)$ & 3214 \\
\cline { 2 - 3 } & 2 days & 14.00 \\
\cline { 2 - 3 } & 7 days & 28.80 \\
\cline { 2 - 3 } & 28 days & 44.30 \\
\hline
\end{tabular}

The table presents the properties of cement used in this study

Table 2. Aggregate properties

\begin{tabular}{|l|c|c|c|c|}
\cline { 2 - 4 } \multicolumn{1}{c|}{} & Size & Density $\left(\mathrm{g} / \mathrm{cm}^{3}\right)$ & Porosity to water & L.A coefficient \\
\hline Natural sand & $0 / 2$ & 2.43 & - & 16.20 \\
\hline \multirow{2}{*}{ Natural aggregate } & $5 / 15$ & 2.70 & $1.46 \%$ & 16.00 \\
\cline { 2 - 4 } & $15 / 25$ & & & 26.00 \\
\hline Recycled aggregate & $8 / 25$ & 2.61 & $6.39 \%$ & - \\
\hline
\end{tabular}

Table presents the properties of aggregates used in this study

Table 3. Mixture proportion $\left(\mathrm{kg} / \mathrm{m}^{3}\right)$

\begin{tabular}{lcccccccccc}
\hline Materials & $\begin{array}{c}\text { NAC } \\
250\end{array}$ & $\begin{array}{c}\text { NAC } \\
300\end{array}$ & $\begin{array}{c}\text { NAC } \\
350\end{array}$ & $\begin{array}{c}\text { NAC } \\
400\end{array}$ & $\begin{array}{c}\text { NAC } \\
450\end{array}$ & $\begin{array}{c}\text { RAC } \\
250\end{array}$ & $\begin{array}{c}\text { RAC } \\
300\end{array}$ & $\begin{array}{c}\text { RAC } \\
350\end{array}$ & $\begin{array}{c}\text { RAC } \\
400\end{array}$ & $\begin{array}{c}\text { RAC } \\
450\end{array}$ \\
\hline Cement & 250 & 300 & 350 & 400 & 450 & 250 & 300 & 350 & 400 & 450 \\
NA $(15 / 25)$ & 801 & 782 & 761 & 741 & 719 & - & - & - & - & - \\
NA (5/15) & 549 & 536 & 522 & 508 & 493 & - & - & - & - & - \\
RA (8/25) & - & - & - & - & - & 1296 & 1267 & 1218 & 1180 & 1139 \\
Natural & 585 & 572 & 557 & 542 & 526 & 582 & 568 & 546 & 530 & 511 \\
sand & 176 & 176 & 178 & 180 & 183 & 180 & 181 & 192 & 196 & 202 \\
Water (L) & 2.31 & 2.34 & 2.40 & 2.45 & 2.46 & 2.26 & 2.30 & 2.35 & 2.40 & 2.44 \\
$\begin{array}{l}\text { Density } \\
\left(\mathrm{g} / \mathrm{cm}^{3}\right)\end{array}$ & & & & & & & & & &
\end{tabular}

This table presents the different proportion of mixture 
Table 4. Compressive strength of studied concrete (MPa)

\begin{tabular}{|c|c|c|c|c|c|c|c|c|c|c|}
\hline Testing age & $\begin{array}{c}\text { NAC } \\
250\end{array}$ & $\begin{array}{c}\text { RAC } \\
250\end{array}$ & $\begin{array}{c}\text { NAC } \\
300\end{array}$ & $\begin{array}{c}\text { RAC } \\
300\end{array}$ & $\begin{array}{c}\text { NAC } \\
350\end{array}$ & $\begin{array}{c}\text { RAC } \\
350\end{array}$ & $\begin{array}{c}\text { NAC } \\
400\end{array}$ & $\begin{array}{c}\text { RAC } \\
400\end{array}$ & $\begin{array}{c}\text { NAC } \\
450\end{array}$ & $\begin{array}{c}\text { RAC } \\
450\end{array}$ \\
\hline 2 days & 5.6 & 5.1 & 8.8 & 8.3 & 9.6 & 8.9 & 11.1 & 10.5 & 12.2 & 11.6 \\
\hline 7 days & 12.0 & 11.5 & 16.5 & 15.2 & 17.7 & 16.9 & 23.8 & 20.2 & 26.7 & 24.3 \\
\hline 28 days & 15.2 & 14.3 & 21.6 & 20.2 & 23.5 & 21.6 & 27.7 & 25.0 & 29.9 & 27.1 \\
\hline
\end{tabular}

This table shows the compressive strength of concrete studied

Table 5. Recycled to natural aggregate concrete strength ratio « $\mathrm{r} »$

\begin{tabular}{|c|c|c|c|}
\cline { 2 - 4 } \multicolumn{1}{c|}{} & \multicolumn{3}{c|}{ Testing ages } \\
\hline Cement content $(\mathrm{kg} / \mathrm{m} 3)$ & 2 days & 7 days & 28 days \\
\hline 250 & 0.89 & 0.96 & 0.94 \\
\hline 300 & 0.94 & 0.92 & 0.94 \\
\hline 350 & 0.93 & 0.95 & 0.92 \\
\hline 400 & 0.95 & 0.85 & 0.90 \\
\hline 450 & 0.95 & 0.91 & 0.91 \\
\hline Average value of $\mathrm{r}$ & 0.93 & 0.92 & 0.92 \\
\hline
\end{tabular}

This table shows the reduction ratio between recycled to natural aggregate concrete

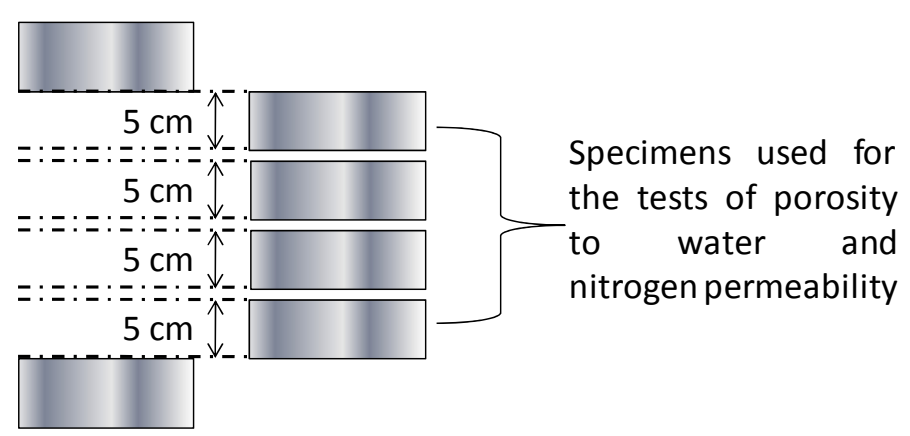

Figure 1. sawed samples used for physical tests

Presentation of the specimens used for physical tests 


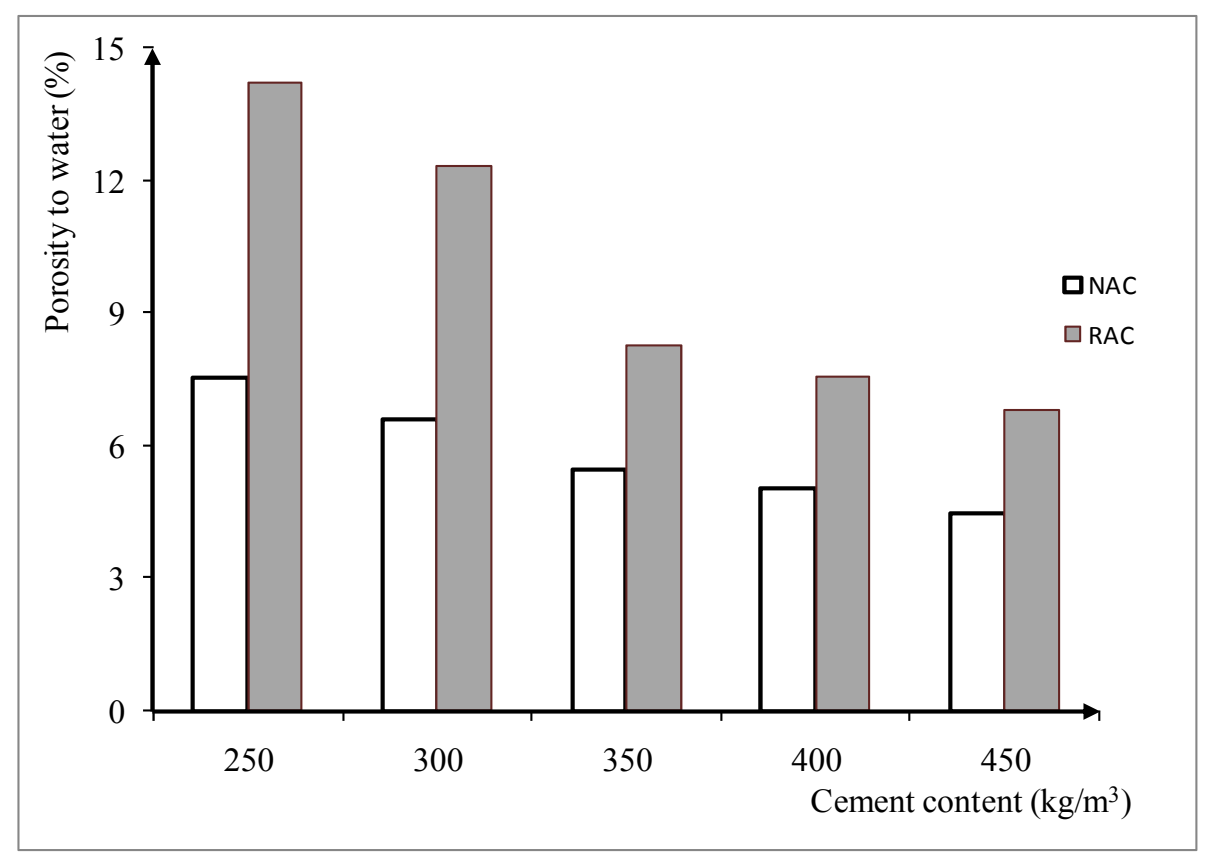

Figure 2. variation of the porosity to water of studied concretes according to cement content Results of measurements of porosity to water of studied concrete

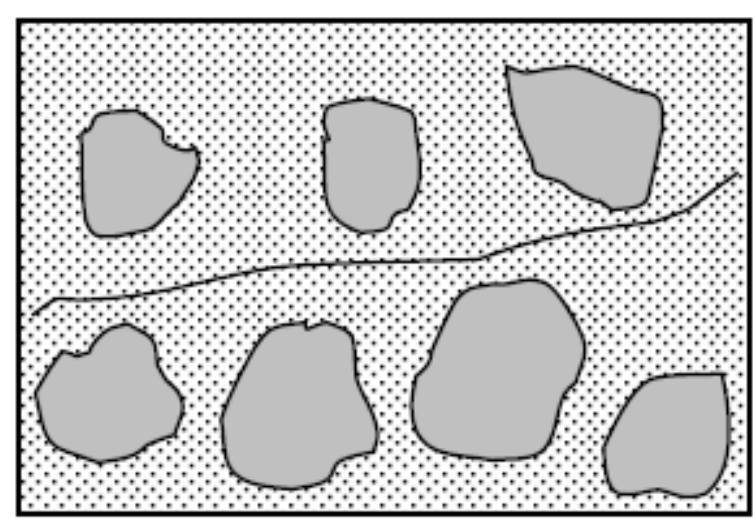

Figure $3 \mathrm{a}:$ Natural aggregate concrete

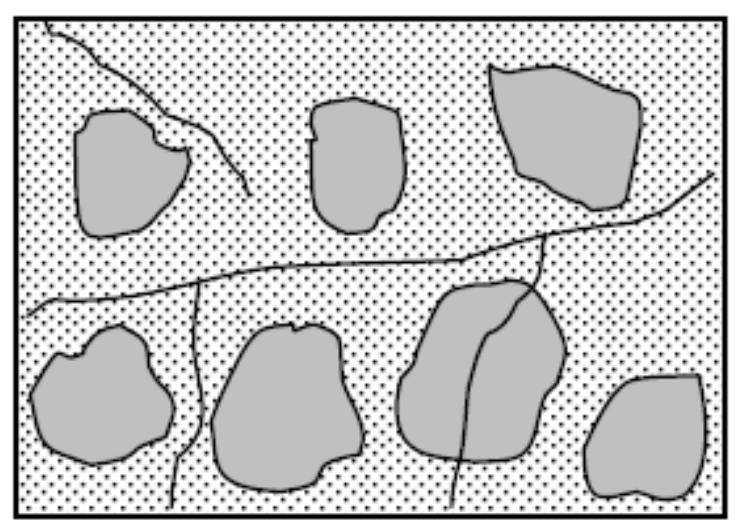

Figure $3 b$ : Recycled aggregate concrete

Figure 3. Preferential path of water according to studied concrete

These figures show the preferential path of water into the two types of concrete 


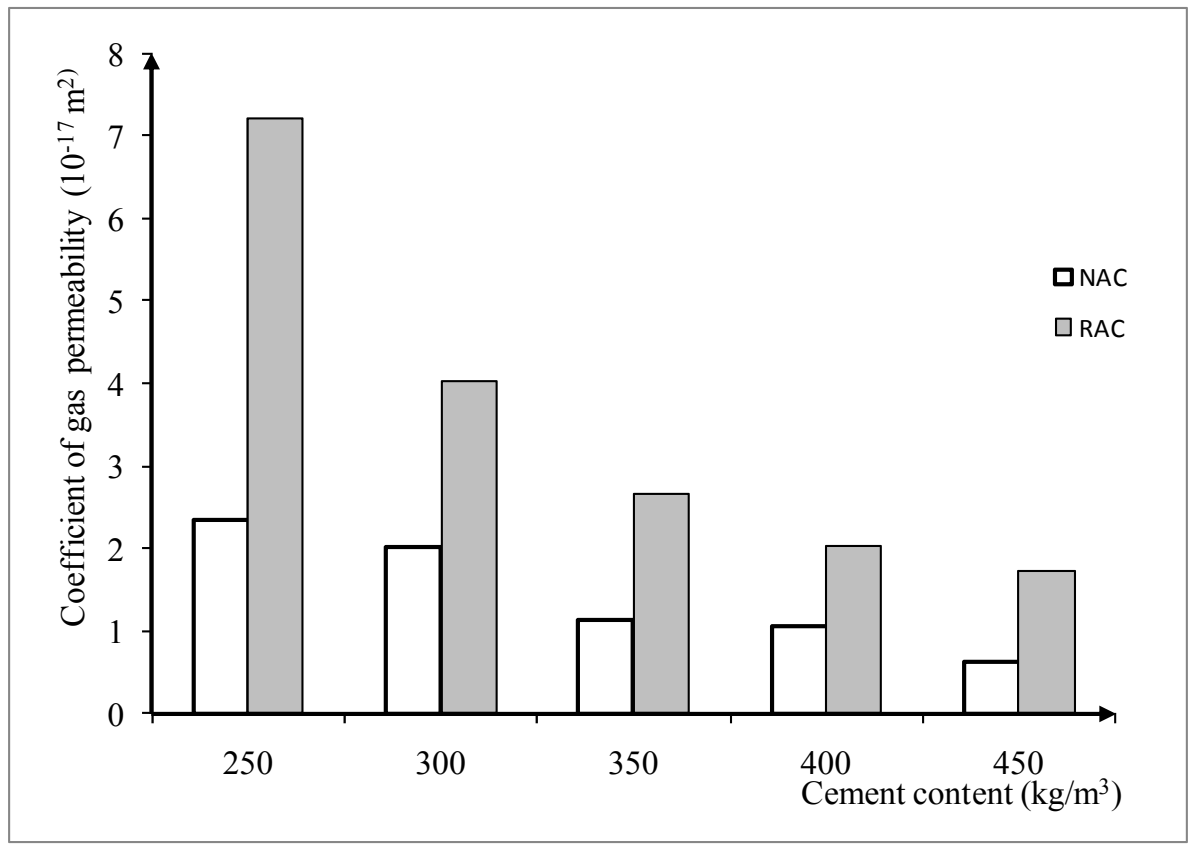

Figure 4. variation of the gas permeability of concretes according to cement content

This figure shows the variation of gas permeability of studied concrete

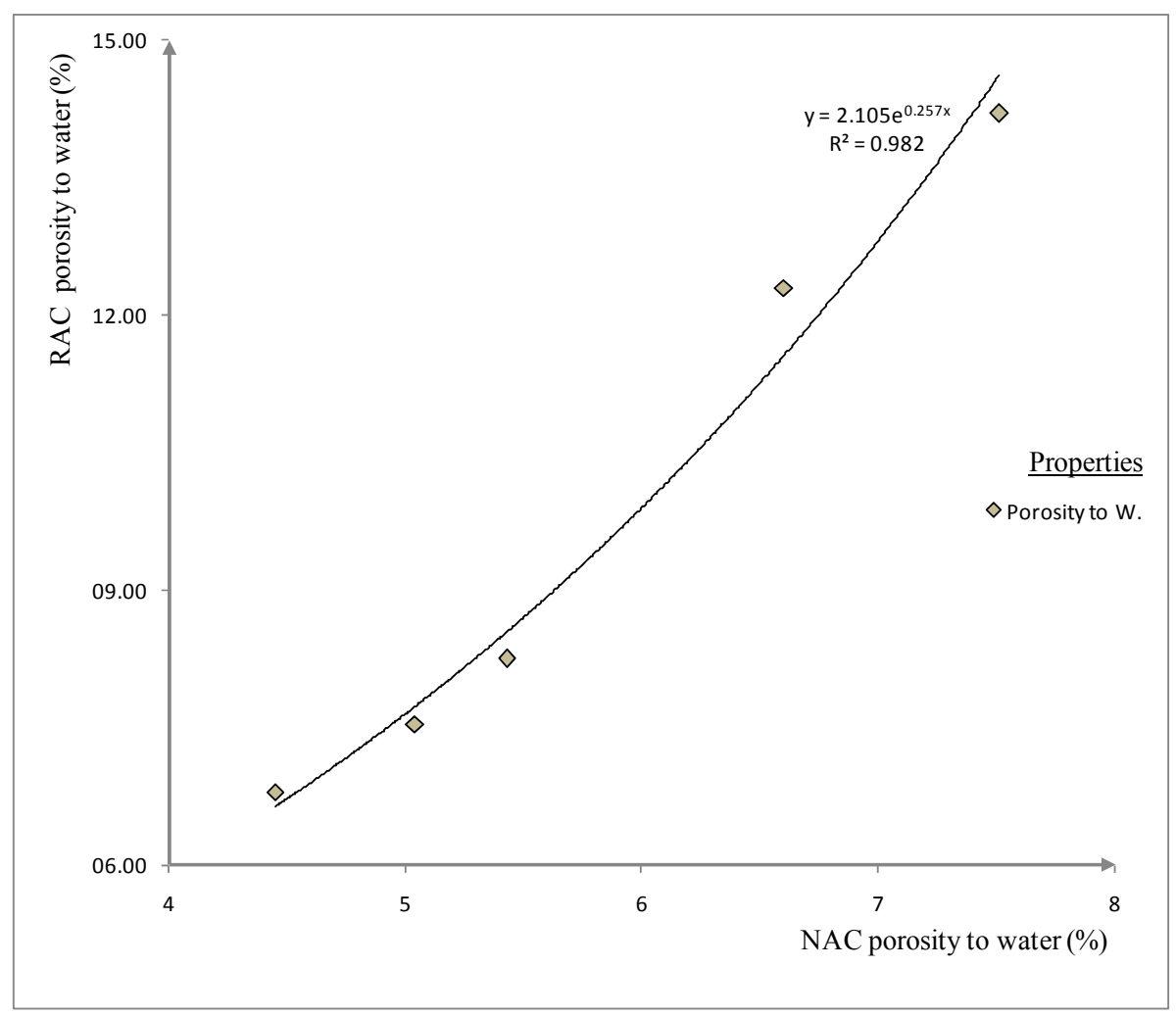

Figure 5. Correlation between recycled aggregates concrete porosity to water and that of natural aggregate concrete

This figure shows correlation between porosity to water of two types of concrete 


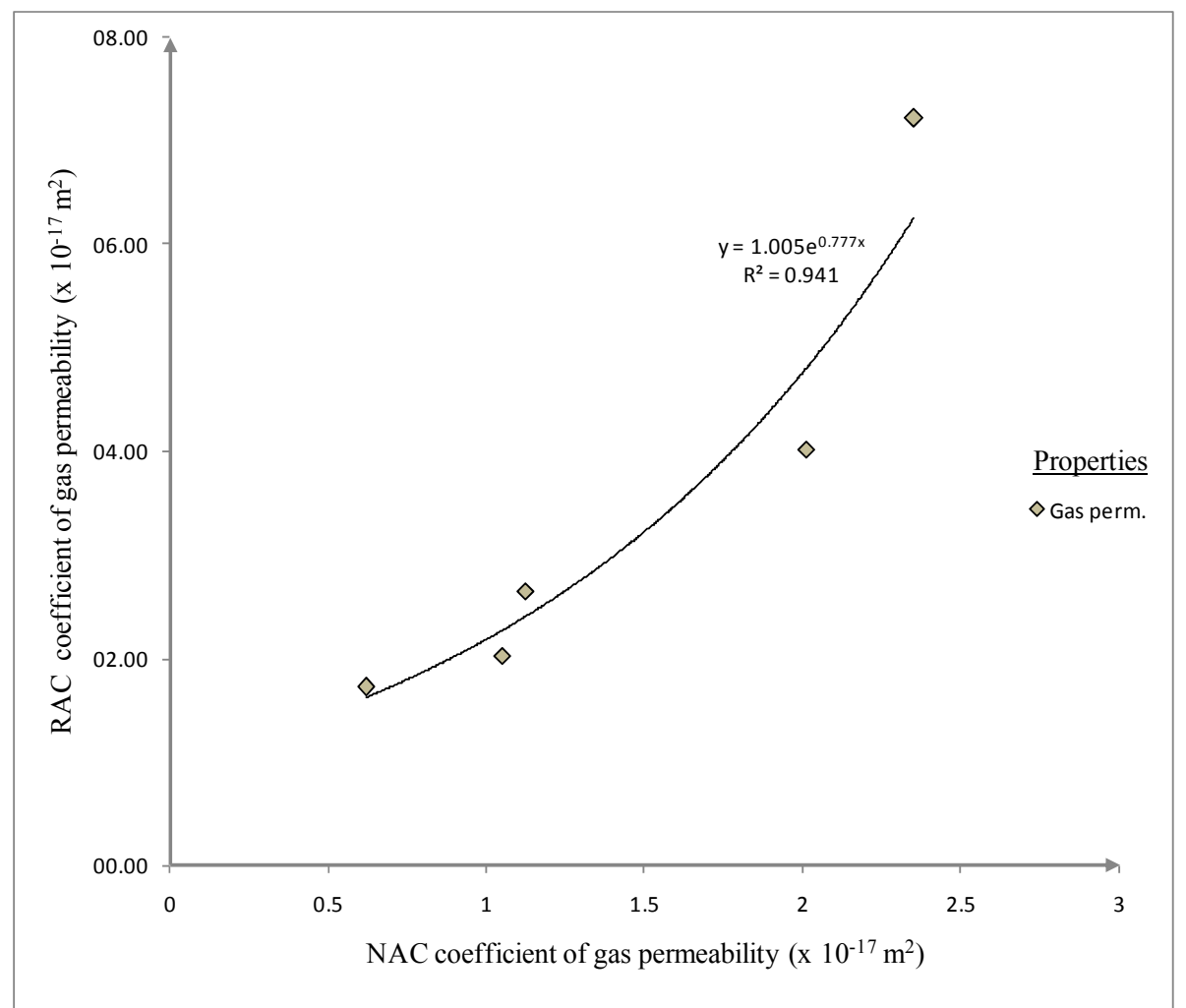

Figure 6. Correlation between recycled aggregates concrete permeability and natural aggregate concrete permeability

This figure shows correlation between gas permeability of two types of concrete

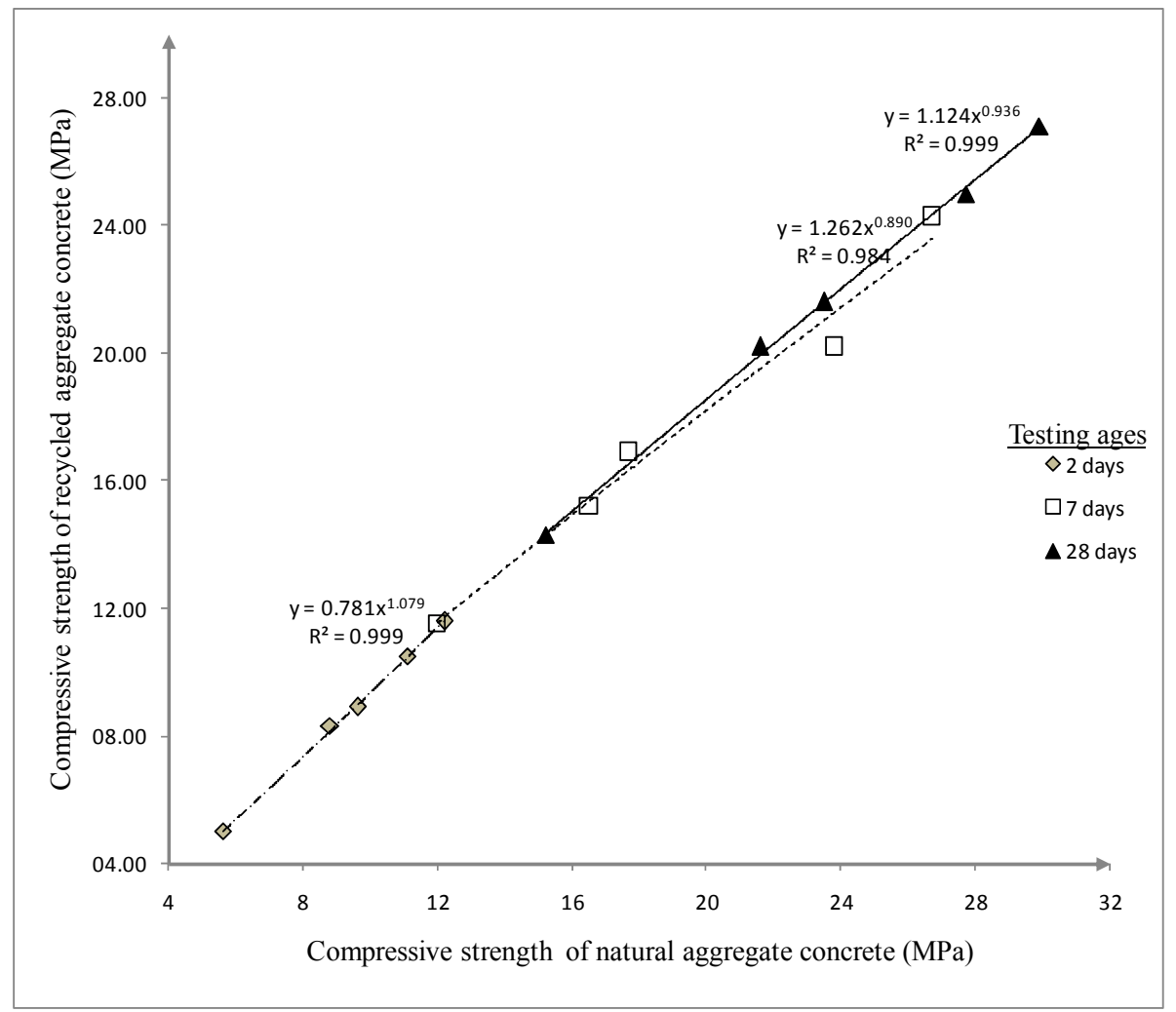

Figure 7. Correlation between recycled aggregates concrete strength and natural aggregate concrete strength This figure shows correlation between compressive strength of two types of concrete 